https://doi.org/10.19195/0524-4544.329.49

\author{
RYSZARD SZOSTAK \\ ORCID: 0000-0002-1364-3772
}

Uniwersytet Ekonomiczny w Krakowie

ryszard.szostak@uek.krakow.pl

\title{
Z problematyki racjonalizacji ograniczeń swobody kontraktowej w zamówieniach publicznych
}

\begin{abstract}
Abstrakt: Swoboda kontraktowa obowiązuje w zamówieniach publicznych pomimo licznych ograniczeń. Dominują ograniczenia ustawowe, charakterystyczne dla parametrycznego sterowania gospodarką, natomiast indywidualna ingerencja administracyjna ma znaczenie drugoplanowe. W zakresie wyboru typu umowy ograniczenia są sporadyczne, ponieważ ustawa nie przesądza o tym, kiedy i jakich zamówień mogą udzielać jednostki sektora publicznego. Także przedsiębiorcy ubiegają się o poszczególne zamówienia na zasadzie dobrowolności. Zakaz transakcji bezpośrednich uzasadnia jednak dotkliwą pod względem biurokratycznym reglamentację procedur udzielania zamówień publicznych, choć wola stron ma tu znaczenie podstawowe, zwłaszcza przy konstruowaniu warunków proceduralnych, a ustawa działa jedynie uzupełniająco. Równie uciążliwe są ograniczenia swobodnego kształtowania treści umowy. Wzrasta zastosowanie klauzul obligatoryjnych, wymuszonych ustawowo, coraz bardziej rygorystyczne są normatywne zasady wykonywania zamówień publicznych, uzasadnione potrzebą wzmożonej ochrony interesu publicznego. Panująca w pozostałym zakresie swoboda nierzadko bywa nadużywana przez zamawiającego, który zawczasu projektuje postanowienia umowy. Dlatego istotne znaczenie praktyczne ma unormowana ostatnio możność zwalczania klauzul abuzywnych w trybie odwoławczym. Jednocześnie, wzmacniając zasadę realnego wykonania zamówienia wykluczającą możnością obchodzenia wyników przetargu, wprowadzono zakaz dokonywania istotnych zmian w umowach o zamówienia publiczne oraz przedwczesnego ich rozwiązywania. Niedogodności formalne i biurokratyczne łagodzić ma postępująca informatyzacja zamówień publicznych.
\end{abstract}

Słowa kluczowe: umowa, swoboda umów, zamówienia publiczne, przetargi. 


\section{Uwagi ogólne}

Swobodę kontraktową w sferze stosunków gospodarczych słusznie łączy się $\mathrm{z}$ nadrzędną zasadą wolności gospodarczej gwarantowaną konstytucyjnie (art. 20), a nawet szerzej - z wolnością jednostki. Na gruncie zamówień publicznych kwestia granic tej swobody ma znaczenie pierwszoplanowe z uwagi na potrzebę licznych ograniczeń uzasadnionych przede wszystkim ochroną interesu publicznego i bezpieczeństwem transakcji. Nie można jednak zgodzić się z występującym niekiedy poglądem, podnoszonym zwłaszcza w praktyce urzędowej, w świetle którego znaczny zakres tych ograniczeń przekreśla zupełnie zasadę swobody umów w zamówieniach publicznych. Po pierwsze, funkcjonuje ona jako zasada kierunkowa, a jej zasadności nie udało się podważyć nawet w okresie gospodarki centralnie planowanej pomimo ograniczeń bardziej rozległych i uciążliwych $^{1}$. W zamówieniach publicznych znajduje ona swoje zastosowanie, choćby wola stron była uszczuplona w przeważającym zakresie. Po drugie, jej obecne unormowanie kodeksowe (art. $353^{1}$ k.c.) odnosi ją do wszelkich kategorii umów obligacyjnych, co w powiązaniu z odesłaniami z art. 14 oraz 139 p.z.p. ${ }^{2}$ pozwala formalnie objąć nią także zamówienia publiczne. W konsekwencji swoboda jest aktualna wszędzie tam, gdzie z ustawy lub zasad współżycia społecznego nie wynika nic innego. Po trzecie, w sferze zamówień publicznych udzielanych na zasadach rynkowych ograniczenia swobody kontraktowej mają zdecydowanie charakter ustawowy, działają bezpośrednio (ex lege), pod rygorem sankcji nieważności czynności prawnej. Ograniczenia indywidualne zaś, zwłaszcza o charakterze administracyjnym, z założenia mają znaczenie drugoplanowe. Pozwalają na zachowanie parametrycznego sterowania zamówieniami udzielanymi na potrzeby zbiorowe, właściwego dla demokratycznego państwa prawnego, wolnego od uciążliwych czynników administracyjno-politycznych. Jest to o tyle doniosłe, że udział zamówień publicznych $\mathrm{w}$ profesjonalnym obrocie zawodowym rośnie sukcesywnie, sięgając już blisko $25 \%$ (ponad $10 \% \mathrm{PKB})^{3}$, mogą one zatem wpływać stymulacyjnie na cały obrót gospodarczy ${ }^{4}$. Po czwarte, ustawowe ograniczenia swobody kontraktowej adresowane są częściowo wyłącznie do samego

1 Por. zwłaszcza A. Wolter, Czy art. 55 kz obowiazuje?, „Nowe Prawo” 1960, nr 10, s. 1480 n.; S. Buczkowski, Zasada wolności umów, „Państwo i Prawo” 1961, nr 3, s. 432 n.; J. Jakubowski, Umowa sprzedaży w handlu międzynarodowym, Warszawa 1966, s. 59 n.; oraz W. Czachórski, Prawo zobowiazań w zarysie, Warszawa 1970, s. 189 n.

2 Ustawa z dnia 29 stycznia 2004 roku Prawo zamówień publicznych (Dz.U. Nr 19, poz. 177); dalej: p.z.p.

3 Por. sprawozdanie Prezesa UZP o funkcjonowaniu systemu zamówień publicznych w 2018 roku, Warszawa 2019, s. 9 n.

${ }^{4}$ Więcej o tym zob. R. Szostak, Zamówienia publiczne instrumentem stymulacji rozwoju gospodarczego, [w:] Prawne instrumenty oddziaływania na gospodarkę, red. A. Powałowski, Warszawa 2016, s. 273 n. 
zamawiającego, któremu nie wolno godzić się na rozwiązania odmienne, pod rygorem sankcji indywidualnej o charakterze administracyjnym, z wyłączeniem odpowiedzialności drugiej strony (wykonawcy). W szczególności dotyczy to obligatoryjnej treści warunków zamówienia (art. 36 ust. 1 p.z.p.), żądania ustanowienia stosownego wadium przetargowego (art. 45 p.z.p.) lub zabezpieczenia należytego wykonania umowy (art. 148 p.z.p.) oraz realizacji obowiązku zawarcia umowy finalnej ze zwycięskim wykonawcą (art. 94 p.z.p.).

Jak wiadomo, swoboda kontraktowa wyrasta z szerzej pojętej autonomii woli i równorzędności stron w stosunkach majątkowych, gwarantowanej wprost konstytucyjnymi założeniami wolności i równości wobec prawa. Na gruncie zamówień publicznych mają one znaczenie fundamentalne, ponieważ pozwalają uwolnić, zarówno samo ich udzielanie (procedury), jak i umowy finalne, od władztwa administracyjnego. Prowadzenie samego postępowania o udzielenie zamówienia na potrzeby zbiorowe, a także ubieganie się o takie zamówienie odbywa się zatem w pełni dobrowolnie. Postępowanie, zwłaszcza przetargowe, toczy się w ramach wielostronnego z natury porozumienia przedkontraktowego o charakterze proceduralnym ${ }^{5}$. Przystępujący swobodnie do przetargu wykonawcy akceptują jego warunki, godząc się także na organizatorską rolę zamawiającego. Zamawiający-organizator działa zatem z upoważnienia cywilnoprawnego uczestników przetargu lub innej procedury toczącej się w ramach z góry ustalonych warunków wyznaczających treść stosunku przedkontraktowego. Nie dysponuje żadnym władztwem administracyjnym. Jedyne przysługujące mu środki dyscyplinujące sprowadzają się do możności wykluczenia wykonawcy z ubiegania się o zamówienie (niedopuszczenia do przetargu) bądź odrzucenia oferty sprzecznej z prawem, dobrymi obyczajami lub ustalonymi warunkami zamówienia. Mają one w pełni charakter cywilnoprawny. Jednocześnie jednak zarówno tok samej procedury wraz z zapadającymi czynnościami, jak i projekt umowy finalnej nie są indywidualnie negocjowane z udziałem wykonawców — z wyjątkiem szczególnego trybu udzielenia zamówienia $\mathrm{z}$ wolnej ręki w układzie dwustronnym. W znacznej części są one z góry ustalane przez zamawiającego-organizatora (przy akceptacji biernej wykonawców), zdeterminowanego działającymi bezpośrednio ograniczeniami ustawowymi. Aktualne jest tu tradycyjne unormowanie, że czynności prawne wywołują nie tylko skutki w niej wyrażone, lecz również te, które wynikają z ustawy, zasad współżycia społecznego i z ustalonych zwyczajów (art. 56 k.c.). Działanie ustawy nie ma więc charakteru bezpośrednio kreacyjnego, a jedynie uzupełniający względem zasadniczej woli stron. Z kolei czynności prawne sprzeczne z ustawą

5 Por. w tym zakresie J. Rajski, Aukcja i przetarg w ujęciu znowelizowanych przepisów kodeksu cywilnego, „Przegląd Prawa Handlowego” 2003, nr 4, s. 8; R. Szostak, Przetarg nieograniczony na zamówienie publiczne — zagadnienia konstrukcyjne, Kraków 2004, s. 163 n.; Z. Radwański, System Prawa Prywatnego, t. 2. Prawo cywilne - część ogólna (suplement), Warszawa 2004, s. 60 n.; oraz M. Krajewski, Zobowiązania powstające podczas zawierania umów, [w:] System Prawa Prywatnego, t. 5. Prawo zobowiązań - część ogólna, red. E. Łętowska, Warszawa 2006, s. 794 n. 
lub z zasadami współżycia społecznego są nieważne (art. 58 k.c.). W tym zakresie chodzi rzecz jasna tylko o normy bezwzględnie obowiązujące i zasady współżycia społecznego (dobre obyczaje), a rola przepisów dyspozytywnych sprowadza się właściwie do regulacji na wypadek braku pozytywnej woli stron, zwyczaj zaś ma znaczenie wyłącznie interpretacyjne. $Z$ punktu widzenia ograniczeń swobody kontraktowej doniosły jest jeszcze wymóg, żeby treść ani cel umowy nie sprzeciwiały się właściwości (naturze) zobowiązania (art. $353^{1}$ k.c.). Autonomia każdego $\mathrm{z}$ wykonawców ubiegających się o zamówienie w ramach procedury konkurencyjnej sprowadza się $\mathrm{w}$ istocie do biernej aprobaty zaproponowanych warunków. Jedynie w trybach negocjacyjno-przetargowych możliwe są negocjacje (wstępne) warunków zamówienia $z$ udziałem zainteresowanych wykonawców, natomiast w przetargu konkurenci dysponują względną swobodą wyłącznie w zakresie kształtowania tych elementów umowy, które z góry objęte zostały kryteriami porównawczej oceny ofert ${ }^{6}$. Dlatego tytułem ochrony interesów wykonawców dopuszcza się (od niedawna) możność zaskarżenia w trybie odwoławczym (do Krajowej Izby Odwoławczej) zarówno niedogodnych wymagań proceduralnych, jak i projektowanych postanowień umowy finalnej, w tym zwalczania klauzul abuzywnych $^{7}$.

\section{Granice swobody kontraktowej}

Swobodzie kontraktowej przypisuje się wielorakie znaczenie. Polega ona co najmniej na nieskrępowanym: a) decydowaniu o samym zawarciu umowy, jej typie i dogodnej technice kontraktowania; b) wyborze kontrahenta; c) kształtowaniu treści stosunku umownego; d) wyborze odpowiedniej formy umowy oraz e) uzgodnieniu ewentualnej zmiany umowy ${ }^{8}$. Niektórzy zwracają uwagę na jeszcze dalsze jej przejawy, na przykład swobodę wyboru sądu (także polubownego) na wypadek sporu między stronami umowy, a inni pomijają zupełnie element formy jako zbyt oczywisty. Coraz częściej spotyka się jednak pogląd przeciwny o potrzebie koncentracji zakresu znaczeniowego tej swobody, według którego możność wprowadzania zmian i uzupełnień do umowy, czy nawet jej przedwczesnego rozwiązania,

${ }^{6}$ Więcej o tym zob. K. Horubski, Prawne uwarunkowania wplywu wykonawców na treść umów o zamówienia publiczne, „Prawo” 329, 2019.

7 Por. w tym zakresie art. 513 pkt 1 in fine ustawy z 11 września 2019 roku Prawo zamówień publicznych (Dz.U. z 2019 r. poz. 2019), dalej: nowe p.z.p.

8 Por. zwłaszcza W. Czachórski, op. cit., s. 189; Z. Radwański, Teoria umów, Warszawa 1977, s. 94 n.; C. Żuławska, Wokół zasady wolności umów (art. $353^{1}$ k.c. i wykładnia zwyczaju), „Prawo” 238, 1994, s. 170 n.; R. Trzaskowski, Granice swobody ksztattowania treści i celu umów obligacyjnych (art. $353^{1}$ k.c.), Kraków 2005, s. 33 n.; oraz P. Machnikowski, Swoboda umów wedtug art. $353^{1}$ k.c. Konstrukcja prawna, Warszawa 2005, s. 20 n. 
mieści się $\mathrm{w}$ istocie $\mathrm{w}$ swobodzie decydowania o zawarciu albo niezawarciu umowy, a dopuszczalność wskazania sądu właściwego łączy się z możnością suwerennego kształtowania treści umowy ${ }^{9}$. Trzeba jednak zgodzić się z dominującym stanowiskiem, że przy analizie swobody umów nie powinno się pomijać kwestii formy czynności prawnej, skoro przepisy narzucające wymóg formy szczególnej utrudniają ewidentnie proces kontraktowania ${ }^{10}$. Sam kodeks nie stwarza tu dostatecznego oparcia, ponieważ nie normuje swobody kontraktowej wyczerpująco. Potwierdza jedynie jej podstawowe elementy, stanowiąc $\mathrm{w}$ art. $353^{1}$, że strony zawierające umowę mogą ułożyć stosunek prawny według swego uznania, byleby jego treść lub cel nie sprzeciwiały się właściwości stosunku, ustawie ani zasadom współżycia społecznego. Jak łatwo zauważyć, ujawniające się w piśmiennictwie różnice wynikają z odmiennego podejścia do problemu, a nie z rzeczywistego zasięgu swobody kontraktowej. W pełnym zakresie odnoszona jest ona jednak tylko do umów obligacyjnych, ponieważ o dopuszczalności i charakterze pozostałych kategorii kontraktów, zwłaszcza prawno-rzeczowych, ustawa przesądza selektywnie, co ma znaczenie także dla zamówień publicznych, które bynajmniej nie wyczerpują się wyłącznie w obrębie stosunków obligacyjnych.

W konsekwencji swobodę kontraktową rozpatruje się w kategoriach kompetencji generalnej wyrażającej się możnością nawiązywania, zmiany lub rozwiazywania stosunków zobowiązaniowych w drodze umownych czynności prawnych. Moc wiążąca umowy obligacyjnej wynika bowiem nie tyle z potrzeby indywidualnego samozwiązania się przyrzekającego świadczenie, ile z konieczności zobiektywizowanej ochrony interesów drugiej strony ${ }^{11}$. Dlatego też próby objaśnienia koncepcji swobody kontraktowej z wykorzystaniem alternatywnej konstrukcji prawa podmiotowego zostały już dawno przez doktrynę odrzucone ${ }^{12}$. Oparcie swobody kontraktowej na wzorcu kompetencji generalnej stało się standardem europejskiego prawa kontraktowego ${ }^{13}$. Dyspozycja 1:102 PECL operuje wyraźnie swobodą zawierania wszelkich umów obligacyjnych oraz kształtowania ich treści ograniczonej wymaganiami dobrej wiary i uczciwego obrotu, a także przepisami bezwzględnie obowiązującymi.

9 Por. zwłaszcza C. Żuławska, Zasady prawa gospodarczego, Warszawa 1995, s. 48 n.; J. Rajski, Prawo o kontraktach w obrocie gospodarczym, Warszawa 2002, s. 57 n.; oraz P. Machnikowski, Swoboda umów, [w:] System Prawa Prywatnego, t. 5, s. 422 n.

10 Por. też Z. Radwański, Teoria umów..., s. 103, który powołuje się w tym zakresie na literaturę niemiecką.

11 Por. zwłaszcza Z. Radwański, [w:] System Prawa Prywatnego, t. 2, s. 10 n. oraz P. Machnikowski, Swoboda umów, [w:] System Prawa Prywatnego, t. 5, s. 424 n.

12 Por. zwłaszcza stanowisko J. Koschembahra-Łysakowskiego, W sprawie kodyfikacji naszego prawa cywilnego, Warszawa 1925, s. 80 n.; oraz polemiczne uwagi A. Ohanowicza, Wolność umów w przyszłym polskim kodeksie cywilnym, „Ruch Prawniczy, Ekonomiczny i Socjologiczny” 1926, nr 3, s. CL.

13 Więcej o tym P. Machnikowski, Swoboda umów, [w:] System Prawa Prywatnego, t. 5, s. 432. 
Swoboda kontraktowa to naturalny czynnik stymulujący postęp techniczny, dobrą jakość świadczenia, elastyczność w kontraktowych sposobach zaspokajania potrzeb gospodarczych, konkurencję i efektywność ekonomiczną transakcji ${ }^{14}$. W zamówieniach publicznych chodzi jeszcze o możliwy wpływ na unowocześnienie i innowacyjność tak zwanego obrotu zaopatrzeniowego oraz świadczenia usług publicznych. Dlatego wszelkie ograniczenia swobody kontraktowej w zamówieniach publicznych muszą być zasadne i umiarkowane. Niezbędna jest ich racjonalizacja, zarówno w sferze stanowienia prawa, jak i jego wykładni. Od razu nasuwa się pytanie o kryteria praktyczne tej racjonalizacji, zwłaszcza w odniesieniu do wykładni przepisów operujących licznymi ograniczeniami proceduralnymi oraz dotyczącymi treści postanowień umownych. W pierwszej kolejności liczą się oczywiście wnioski płynące z przepisów imperatywnych, które nie mogą kolidować z zasadami ustroju gospodarczego, a także z podstawowymi wymaganiami udzielania zamówień publicznych. Jako wyjątkowe — na gruncie swobody kontraktowej - sprzeciwiają się jakiejkolwiek wykładni rozszerzającej. Muszą być stosowane przede wszystkim w zgodzie z podstawowymi zasadami udzielania zamówień publicznych skorelowanymi z rozwiązaniami europejskimi. Wobec rozbudowy tych wyspecjalizowanych reguł tradycyjne dobre obyczaje (reguły współżycia społecznego) odgrywają mniejszą rolę w zamówieniach publicznych niż w stosunkach obrotu powszechnego, $\mathrm{z}$ wyjątkiem rzecz jasna reguł uczciwej konkurencji. Z kolei kodeksowy wymóg, aby umowa w swej treści lub celu nie godziła $\mathrm{w}$ naturę (właściwości) zobowiązania, także traci nieco na znaczeniu w zamówieniach publicznych, ponieważ na ogół są one związane z „obsługą” zadań statutowych jednostek sektora publicznego zapewnianą z udziałem profesjonalnej kadry zarządzającej.

Obok ogólnego wymogu przestrzegania legalności, rzutującego wprost na zasadę powszechności stosowania ustawowego reżimu zamówień publicznych (art. 7 ust. 3 p.z.p.), doniosłe są też wymogi celowości i efektywności ekonomicznej transakcji, lecz nie mogą one popadać w sprzeczność z koniecznością działania w pełni legalnego. Poza tym efektywność należy łączyć także ze skutecznością zamówienia $\mathrm{w}$ zakresie zaspokojenia potrzeb publicznych. Zapewnienie równego dostępu do zamówień finansowanych ze środków publicznych w połączeniu z nakazem równego traktowania konkurentów i poszanowania reguł

14 Wymóg zachowania dostatecznej efektywności transakcji, normowany dotychczas jedynie w aspekcie finansowym (por. art. 44 ust. 3 ustawy z 27 sierpnia 2009 roku o finansach publicznych, Dz.U. z 2019 r. poz. 869), trafił ostatecznie do katalogu zasad udzielania zamówień publicznych. Według nowego art. 17 nowego p.z.p zamawiający udziela zamówienia w sposób zapewniający najlepszą jakość zamawianego świadczenia, uzasadnioną charakterem zamówienia, w ramach posiadanych środków, oraz uzyskaniem najlepszych efektów zamówienia, w tym efektów społecznych, środowiskowych i gospodarczych. 
uczciwej konkurencji to doniosłe wymogi traktatowe ${ }^{15}$ narzucające potrzebę operowania proeuropejską wykładnią krajowych rozwiązań normatywnych ograniczających swobodę kontraktową.

Na dalszym planie są jeszcze zasady przejrzystości i proporcjonalności, które nadal oczekują na swoje ustawowe zdefiniowanie. Procedura przejrzystego udzielania zamówienia polega na postępowaniu opartym na jednoznacznych i wyczerpujących warunkach, kształtowanych przez zamawiającego w zgodzie z ustawą, toczącego się $\mathrm{w}$ ramach przewidywalnego toku czynności prowadzonego rzetelnie przez zamawiającego-organizatora. Przejrzystość wyostrza obraz i pobudza realną konkurencję, wzmacnia zaufanie do końcowego wyboru oferty, pozwala też urzeczywistnić dobre obyczaje. Sprzyja zatem nie tylko ochronie interesu publicznego, lecz także indywidualnego, pomiędzy którymi nie powinno być w tym zakresie sprzeczności. Każdy konkurent, przed wdaniem się w przetarg albo inną procedurę, musi mieć możność dostatecznego oszacowania ryzyka kontraktowego, choćby tylko dlatego, że naraża się na koszty i inne nakłady na przygotowanie oferty, nie mając pewności uzyskania zamówienia ${ }^{16}$. $\mathrm{Z}$ kolei zasada proporcjonalności to postulat adresowany do zamawiającego co do odpowiedzialnego kształtowania warunków i wymagań proceduralnych oraz stosowania środków prawnych, wyłącznie niezbędnych (wystarczających) do osiągniecia zakładanych celów. Każdorazowo muszą być one umiarkowane i uzasadnione, adekwatne do konkretnych sytuacji. Chodzi przede wszystkim o uwzględnienie interesów wykonawców ubiegających się o zamówienia publiczne, aby obciążające ich wymagania i wszelkie formalności były wyważone, a nie chybione lub zbyt uciążliwe. Odnosi to także do postanowień umowy finalnej proponowanych przez zamawiającego, które - jako niewynegocjowane indywidualnie - muszą podlegać kontroli władzy publicznej. Klauzule abuzywne, niekorzystne dla wykonawcy lub zbyt „wygórowane”, zwłaszcza naruszające ekwiwalentność świadczeń objętych kontraktem wzajemnym, powinny być zwalczane zawczasu, jeszcze przed zawarciem umowy finalnej, ponieważ później pozostaje właściwie tylko unieważnienie umowy sprzecznej z prawem, nie licząc przypadków szczególnych, jak na przykład zwalczania wyzysku w ujęciu art. 388 k.c., sądowego miarkowania kary umownej (art. 484 § 2 k.c.) czy zastosowania klauzuli rebus sic stantibus (art. $357^{1}$ k.c.). Dlatego swoboda kontraktowa w kształtowaniu postanowień umowy nie może przekraczać granic, za którymi dochodzi do nadużycia uprzywilejowanej pozycji lub innego niemoralnego wykorzystania przewagi faktycznej nad drugą stroną kontraktu. W razie zaś nieusuwalnych wątpliwości interpretacyjnych co do zakresu lub celu ograniczenia swobody sięgać trzeba do wykładni funkcjonalnej, z uwzględnieniem zasad udzielania zamówień publicznych.

15 Por. A. Sołtysińska, Europejskie prawo zamówień publicznych. Komentarz, Warszawa 2016, s. 245 n.

16 Więcej zob. R. Szostak, Jawność i przejrzystość postępowania o udzielenie zamówienia publicznego, „Samorząd Terytorialny” 2019, nr 5, s. 9 n. 


\section{Wybór typu umowy o zamówienie publiczne}

W zakresie możności decydowania o zawarciu albo niezawarciu umowy swoboda kontraktowa jest największa. W szczególności prawo zamówień publicznych nie przesądza o tym, czy i jakich zamówień mogą udzielać jednostki sektora publicznego. Zamawiający sami rozstrzygają o tym, czy określone potrzeby zbiorowe zostaną zaspokojone przez świadczenia umowne, czy inaczej, zwłaszcza sposobem gospodarczym. Nie są też skrępowani co do wyboru typu umowy, można na przykład samochód kupić na własność, wziąć w leasing albo wynająć. Podobnie wykonawcy mogą in casu suwerennie decydować o ubieganiu się o poszczególne zamówienia publiczne. Wprawdzie zamawiający są ograniczeni administracyjnie, co najmniej statutowym zakresem swojego działania i dyspozycjami planów rzeczowo-finansowych, jednak obecnie przekroczenie tych barier nie jest już obarczone sankcją nieważności umowy ${ }^{17}$, lecz odpowiedzialnością osobistą urzędników naruszających obowiązujące zasady zaciągania zobowiązań. Ostatnio wprowadzono jednak administracyjną powinność uprzedniej analizy potrzeb i wymagań w ujęciu art. 83 nowego p.z.p. Działa też swoista kontrola finansowa w postaci tak zwanej kontrasygnaty zobowiązania przez głównego księgowego (skarbnika). Mają one na celu, podobnie jak wymogi należytego opisu i oszacowania przedmiotu zamówienia, zapewnienie dostatecznej efektywności transakcji po stronie zamawiającego (pod rygorem odpowiedzialności karno-administracyjnej urzędników); nabierają charakteru czysto wewnętrznego, nie rzutują bezpośrednio na skuteczność umowy finalnej. Potrzeba ochrony interesów drugiej strony transakcji jest tu oczywista. Nieliczne wyjątki na rzecz nieważności całej umowy wynikają jednak z ustawy, jak na przykład w odniesieniu do zobowiązań pożyczkowo-kredytowych jednostek samorządu terytorialnego zaciąganych bez należytej kontrasygnaty skarbnika. Z kolei wykonawcy ubiegający się o zamówienia publiczne muszą być dostatecznie wiarygodni, a wymóg ten obowiązuje nawet w trybie udzielania zamówienia z wolnej ręki, w imię zachowania niezbędnej efektywności transakcji i ochrony interesu publicznego. Wiarygodny wykonawca to podmiot zdolny do należytego wykonania zamówienia i nieszkodzący interesom publicznym (por. wykluczenia $z$ art. 24 p.z.p.), rzetelnie dokumentujący swoje warunki i właściwości osobiste. Wyłudzenie zamówienia z pogwałceniem wymagań dotyczących weryfikacji wiarygodności wykonawcy uzasadnia jednak odstąpienie od umowy finalnej (art. 145a pkt 2 p.z.p.) lub jej unieważnienie w trybie art. 146 ust. 6 p.z.p., niezależnie od ewentualnej odpowiedzialności karnej samego sprawcy (por. np. art. 297 k.k.).

17 Tak jak dawniej na gruncie poprzednio obowiązującego art. 36 k.c. Zob. o tym zwłaszcza S. Grzybowski, Prawo cywilne - zarys części ogólnej, Warszawa 1974, s. 159-160. 


\section{Kształtowanie wymagań proceduralnych}

Zakaz transakcji bezpośredniej, połączony z koniecznością zastosowania procedury ustawowo przewidzianej, stanowi najbardziej dotkliwe ograniczenie swobody kontraktowej. Zgodnie z dyspozycją art. 7 ust. 3 p.z.p. zamówienia publicznego udziela się wyłącznie wykonawcy wybranemu zgodnie z przepisami ustawy. Pominięcie nakazanej procedury bądź istotne naruszenie jej toku lub wymagań pociąga za sobą unieważnienie umowy finalnej. Tymczasem rodzaj procedury wybiera i wymagania kształtuje zamawiający. Wprawdzie wykonawca może dochodzić ewentualnej korekty uchybień organizatorskich w trybie odwoławczym, jednak tylko w granicach ochrony przed naruszeniami swoich interesów. O zasadności wybranej procedury przesądzają na ogół okoliczności leżące po stronie zamawiającego. Dlatego „wciągnięcie” wykonawcy do umowy nieważnej bezwzględnie lub podlegającej unieważnieniu z przyczyn po stronie zamawiającego musi pociągać odpowiedzialność odszkodowawczą na zasadach ogólnych, podobnie jak w wypadku odwrotnym polegającym na zaciągnięciu przez wykonawcę zobowiązania o świadczenie niemożliwe (art. 387 k.c.) ${ }^{18}$. Zamawiający kształtujący wymagania proceduralne, zwłaszcza przetargowe, które nie są indywidualnie negocjowane, ponosi zatem większe ryzyko popełnianych nieprawidłowości niż w zwyczajnych okolicznościach. Dlatego wszelkie proceduralne ograniczenia swobody kontraktowej powinny być racjonalne i umiarkowane, w zgodzie z zasadą proporcjonalności. Na tle powyższego ograniczenie liczby procedur w nowym prawie zamówień publicznych, a także wprowadzenie licznych uproszczeń połączonych z poprawą przejrzystości postępowania spotkały się z powszechną aprobatą. Od tej tendencji odbiega nieco powinność zastosowania procedury ofertowej uruchamianej na podstawie ogłoszenia przy udzielaniu zamówień bagatelnych o wartości powyżej 50 tysięcy złotych, a także wymóg obligatoryjnego zastosowania konkursu przy zamawianiu architektonicznych dzieł projektowych lub prac architektoniczno-budowlanych, które stanowią odpowiedź na negatywne praktyki wielu zamawiających, unikających konkurencyjności postępowania ze szkodą dla efektywności gospodarczej zamówienia. Z kolei intensywnie zwalczane od paru lat przypadki nadużywania procedur — udzielenia zamówienia z wolnej ręki, negocjacji bez ogłoszenia bądź trybu zapytania o cenę

18 Według dyrektywy 2007/66 Parlamentu Europejskiego i Rady z dnia 11 grudnia 2007 roku o poprawie skuteczności procedur odwoławczych w zamówieniach publicznych (Dz.Urz. z 2007 r. L 335, 20.12.2007, s. 31) odpowiedzialność zamawiającego za szkody wyrządzone wykonawcom nie może być uzależniona od winy. Aktualne unormowanie odpowiedzialności kontraktowej na zasadach ogólnych (art. 471 k.c.), jak i deliktowej (art. 415 k.c.) nie spełniają zatem tego standardu. Niezbędne jest wprowadzenie lex specialis, najlepiej poprzez rozciągniecie obecnego rozwiązania z art. 93 ust. 4 p.z.p. (art. 261 nowego p.z.p.) na wszelkie inne przypadki wyrządzenia szkody. Więcej o tym zob. R. Szostak, Odpowiedzialność organizatora przetargu za szkody wyrządzone konkurentom, „Państwo i Prawo” 2011, nr 10, s. 46 n. wraz z powołanym tam orzecznictwem TSUE. 
— przyczyniło się do istotnego spadku ich zastosowania na rzecz radykalnego wzrostu zainteresowania procedurami przetargowymi ${ }^{19}$.

W ramach przetargowego sposobu wyboru oferty najkorzystniejszej, dominującego w praktyce, wyklucza się modyfikacje polegające na wprowadzeniu dodatkowych elementów procedury. W szczególności w świetle art. 87 ust. 1 p.z.p. niedopuszczalne jest prowadzenie między zamawiającym a wykonawcą negocjacji dotyczących złożonej oferty oraz dokonywania jakiejkolwiek zmiany w jej treści. Aktualnie dopuszcza się dwa wyjątki, natomiast nowa ustawa wprowadza jeszcze trzecie odstępstwo. Po pierwsze, jeśli zamawiający dopuścił aukcję elektroniczną, uruchamianą po ocenie złożonych ofert (art. 91a p.z.p.), każdy z konkurentów utrzymujących się w przetargu może wyłącznie w drodze elektronicznej polepszyć swoją ofertę (tak zwana dogrywka). Po drugie, można skorygować tak zwane nieistotne omyłki w ocenianej ofercie, polegające na „niezgodności oferty z warunkami (dokumentami) zamówienia, niepowodujące istotnych zmian w treści oferty". W tym celu zamawiający wyznacza wykonawcy odpowiedni termin na wyrażenie zgody na poprawienie w ofercie omyłki, a nieudzielenie odpowiedzi w wyznaczonym terminie uznaje się za wyrażenie zgody. W istocie chodzi tu o zmianę oferty na podstawie jednostronnego oświadczenia woli wykonawcy zainicjowanego jedynie przez zamawiającego-organizatora. Zaniechanie korekty prowadzi do odrzucenia oferty z uwagi na jej sprzeczność z warunkami zamówienia. Najważniejsze jednak jest to, że liczy się wyłącznie „omyłka” (błąd), a nie świadomie popełniona niezgodność, na dodatek tylko „nieistotna” w swoim charakterze i rozmiarze konsekwencji. Tymczasem w praktyce, a nawet w orzecznictwie, legalizuje się niekiedy w sposób niedopuszczalny korekty przekraczające próg drobnej nieistotności. Po trzecie, nowością będzie możność fakultatywnego zastosowania modyfikacji przetargowego wyboru oferty na zamówienie mniejszej wartości (poniżej europejskiego progu kwotowego) poprzez zastrzeżenie negocjacji dodatkowych w zakresie elementów objętych kryteriami oceny ofert połączonych ze składaniem tak zwanych ofert ostatecznych albo negocjacji zmierzających do polepszenia minimalnych wymagań (parametrów) przedmiotu zamówienia w celu podniesienia jego efektywności ekonomicznej. Rozwiązanie to niewątpliwie wzbogaca możliwości proceduralne w kierunku poszerzenia swobody kontraktowej, choć w praktyce może okazać się dyskusyjne, jeżeli sprzyjać będzie naruszeniom wymagań równego traktowania wykonawców i uczciwej konkurencji.

Pozytywnie natomiast trzeba odnieść się do rozwiązania z art. 263 nowego p.z.p., zgodnie z którym jeżeli zwycięski wykonawca uchyla się od zawarcia umowy finalnej lub wymaganego jej zabezpieczenia, zamawiający może wybrać inną ofertę dopiero po przeprowadzeniu ponownej oceny wszystkich ofert utrzymujących się w przetargu, a nie tak jak obecnie - kolejną ofertę według pierwotnego

19 Por. sprawozdanie powołane w przyp. 2. 
rankingu ofert (art. 94 ust. 5 p.z.p.). Należy jednak ubolewać nad tym, że brakuje w nowej ustawie dostatecznej przejrzystości co do mechanizmu obowiązku zawarcia umowy finalnej. Dopiero w drodze pośredniej interpretacji uwzględniającej regulacje kodeksowe (art. $70^{2} \S 3 \mathrm{z}$ odesłania z art. $70^{3} \S 3$ k.c.) dochodzi się do wniosku, że wybór oferty najkorzystniejszej prowadzi do jej przyjęcia, a w rezultacie do nawiązania dwustronnego stosunku przejściowego, analogicznego jak z umowy przedwstępnej (art. 389-390 k.c.) ${ }^{20}$. Dwustronny obowiązek zawarcia umowy finalnej podlega zatem standardom kodeksowym $w$ zakresie terminu jej zawarcia, z możliwą jego prolongatą, jak i w zakresie konieczności uprzedniego rozwiązania obligu z wybranym wykonawcą w celu uruchomienia odpowiedzialności wadialnej, a tym bardziej w celu ponownego wyboru kolejnej oferty.

Spośród pozostałych wymagań proceduralnych istotne znaczenie mają ustawowe podstawy odrzucenia oferty oraz zasady kształtowania kryteriów oceny ofert. Katalog podstaw odrzucenia oferty ciągle poszerza się, uszczuplając — niestety zakres swobody kontraktowej. Częściowo jednak stanowi on wynik kazuistycznego podejścia ustawodawcy do regulacji tej kwestii. $\mathrm{W}$ istocie na odrzucenie zasługuje oferta sprzeczna z prawem, dobrymi obyczajami lub ukształtowanymi indywidualnie warunkami zamówienia. Na tle zarówno aktualnie obowiązującego, jak i znowelizowanego wykazu nasuwa się potrzeba operowania w pierwszej kolejności taką właśnie formułą generalną, a następnie wyliczeniem przykładowym przypadków szczególnych. Operowanie zaś katalogiem zamkniętym nastręcza nieustających trudności w odniesieniu do przypadków wyraźnie nieunormowanych. W ramach art. 226 nowego p.z.p. kazuistyczny wykaz podstaw odrzucenia oferty powiększył się niemal dwukrotnie, choć części z nich można by uniknąć, zwłaszcza tych, które wynikają wprost $\mathrm{z}$ naruszenia ustalonych warunków zamówienia. Poza tym niektóre przypadki są dyskusyjne. Przykładowo, przypadek oferty dotkniętej błędem w obliczeniu ceny (kosztu) od dawna budzi kontrowersje, ponieważ chodzi tu nawet o błąd nieistotny, o ile nie zostanie skorygowany w trybie tak zwanej nieistotnej zmiany oferty, lecz tylko pod warunkiem sprzeczności kalkulacji ofertowej z jej formułą zawartą w warunkach zamówienia. W praktyce dochodzi niekiedy do paradoksalnej sytuacji, w której drobne przeoczenie w obliczeniu ceny w jednej ofercie nie może zostać skorygowane, podczas gdy w innej nieco większy w skutkach błąd podlega korekcie. Z kolei przypadek nieważności oferty na podstawie odrębnych przepisów nie powinien być uznawany za podstawę jej odrzucenia, skoro oferta taka, jako ipso iure bezskuteczna, powinna być zwyczajnie wyłączona z przetargu, a nie „wygaszana” w drodze odrzucenia. Z braku odmiennych skutków odrzucenia oferty stosuje się rozwiązanie kodeksowe, zgodnie z którym oferta odrzucona wygasa $\mathrm{z}$ chwilą doręczenia oferentowi stosownego oświadczenia woli.

20 Por. zwłaszcza J. Rajski, Aukcja i przetarg..., s. 8; C. Żuławska, Komentarz do kodeksu cywilnego. Księga trzecia - zobowiązania, t. 1, Warszawa 2005, s. 166; oraz R. Szostak, Przetarg nieograniczony..., s. $163 \mathrm{n}$. 
Zasada, że zamówienia publicznego udziela się wyłącznie wykonawcy wybranemu w zgodzie z ustawą, wyklucza także możność pochodnego przejęcia zamówienia publicznego przez osobę trzecią, która nie poddała się rygorom nakazanej procedury. Dopuszczalne wyjątki określa ustawa w art. 144 ust. 1 pkt 4 p.z.p. Ich racjonalizacja $\mathrm{w}$ zgodzie $\mathrm{z}$ dyrektywami europejskimi na mocy art. 455 ust. 1 pkt 2 nowego p.z.p. spotka się zapewne z przychylną oceną w piśmiennictwie. Chodzi tu przede wszystkim o ochronę uczciwej konkurencji oraz zapobieganie ,przechwytywaniu" zamówień przez niewiarygodnych wykonawców ze szkodą dla interesów publicznych; nie bez znaczenia jest także zwykła troska o przeciwdziałanie obejściu prawa. Osoba trzecia może zastąpić dotychczasowego wykonawcę, jeżeli możliwość taka została z góry zastrzeżona (na przykład na rzecz filii wykonawcy), a także w wyniku sukcesji, o ile nowy wykonawca spełnia warunki ubiegania się o zamówienie, albo w wyniku przejęcia przez zamawiającego zobowiązań wykonawcy względem jego podwykonawców, a to w następstwie zapłaty przez zamawiającego należnego im wynagrodzenia, choć w tym ostatnim wypadku wejście podwykonawcy w rolę wykonawcy jest tu możliwe rzecz jasna tylko częściowo.

\section{Zastosowanie formy elektronicznej czynności}

Specjalne znaczenie mają standardy urzędowe informatyzacji oraz kształtowane in casu przez zamawiającego indywidualne wymagania informatyzacyjne. Wprowadzenie wymogu komunikacji elektronicznej zamawiającego z wykonawcami, zwłaszcza przy składaniu ofert (wniosków) i dokumentów im towarzyszących, przejściowo bywa uciążliwe, lecz wymuszone zostało potrzebą przyspieszenia $i$ uproszczenia obiegu informacji oraz ułatwienia obsługi biurokratycznej przetargów i innych procedur. Zasadności informatyzacji zamówień publicznych nikt nie kwestionuje, tym bardziej że następuje ona pod przemożnym wpływem rozwiązań europejskich. Tymczasem wszelkie nowe formalności ograniczają wyraźnie swobodę kontraktową. $\mathrm{Z}$ tego względu praktycznie doniosłe są gwarancje ustawowe zawarte $\mathrm{w}$ art. 10a-f p.z.p. W szczególności zamawiający powinien zapewnić każdorazowo, aby narzędzia i urządzenia wykorzystywane do komunikacji elektronicznej, a także ich właściwości techniczne były niedyskryminujące, ogólnie dostępne oraz interoperacyjne z produktami służącymi do przekazu, przetwarzania i gromadzenia danych będących w powszechnym użyciu i nie ograniczały wykonawcom dostępu do zamówień publicznych ${ }^{21}$. Doniosłe są też pouczenia oferentów o formacie i parametrach przekazu informacji oraz wymaganiach technicznych sprzętu. Wymóg zastosowania surowszej formy elektronicznej

${ }^{21}$ Więcej o tym zob. M. Moras, [w:] Informatyzacja procedur udzielania zamówień publicznych, red. R. Szostak, Warszawa 2018, s. 187 n. 
z kwalifikowanym podpisem powinien być zarezerwowany, w zgodzie z zasadą proporcjonalności, właściwie tylko do składania ofert (wniosków) i dokumentów towarzyszących. Wprowadzone niedawno zasady komunikacji elektronicznej w postępowaniu o udzielenie zamówienia publicznego zostały nieco rozwinięte i udoskonalone w ramach art. 61-70 nowego p.z.p., jednak obowiązek ich przestrzegania dotyczy nadal tylko relacji zamawiający-wykonawcy, natomiast czynności osób trzecich (na przykład ustanowienie wadium poręczycielskiego lub gwarancyjnego) nie muszą już podlegać rygorom formy elektronicznej.

Umowa finalna o zamówienie publiczne powinna być zawarta, pod rygorem nieważności, w formie pisemnej, chyba że przepisy odrębne wymagają innej formy szczególnej. Warunki zachowania formy pisemnej mają wymiar powszechny, wynikają z kodeksu cywilnego. Kluczowe znaczenie ma też prawidłowe umocowanie do podpisania umowy zawieranej za pośrednictwem pełnomocnika lub prokurenta, choć w razie działania osoby bez umocowania lub z przekroczeniem jego zakresu ważność umowy zależy od jej potwierdzenia przez stronę nieprawidłowo reprezentowaną (art. 103 k.c.). Za zastępczą wobec pisemnej uważa się formę elektroniczną z kwalifikowanym podpisem, ponieważ w świetle art. 78 $\S 2$ k.c. oświadczenie woli złożone w formie elektronicznej jest równoważne $\mathrm{z}$ oświadczeniem woli złożonym $\mathrm{w}$ formie pisemnej. Unormowanie to poszerza nieco zakres swobody kontraktowej, jest w pełni aktualne do umów o zamówienia publiczne. W piśmiennictwie zaznaczył się słuszny pogląd o dopuszczalności tak zwanej formy hybrydowej, gdy jedna ze stron działa na piśmie, a druga elektronicznie $^{22}$.

\section{Kształtowanie treści umowy finalnej}

Ograniczenia swobody w kształtowaniu treści umowy o zamówienie publiczne także sukcesywnie wzrastają. Potrzeba racjonalizacji jest tu najbardziej aktualna. Dodatkowo zaostrza się problem dotkliwej redukcji swobody faktycznej wykonawców przy konstruowaniu umowy projektowanej jednostronnie przez zamawiającego, z pominięciem negocjacji indywidualnych, dopuszczalnych jedynie $\mathrm{w}$ zakresie niewiele znaczących procedur negocjacyjno-przetargowych oraz w ramach trybu udzielenia zamówienia z wolnej ręki. W dominującym zaś trybie przetargowym, podobnie jak przy umowach adhezyjnych, dochodzi do biernej akceptacji ze strony wykonawcy ustalonej przez zamawiającego treści umowy finalnej, z wyjątkiem kilku postanowień objętych kryteriami oceny ofert, na które z kolei decydujący wpływ ma zwycięski wykonawca. W rezultacie tylko w pew-

22 Por. M. Drozdowicz, Zawarcie umowy o zamówienie publiczne w formie elektronicznej, „Prawo Zamówień Publicznych” 2019, nr 2, s. 55 n. 
nym zakresie kontrahenci współkonstruują treść umowy, choć w warunkach wyraźnej przewagi faktycznej (lecz nie prawnej) zamawiającego. $Z$ drugiej jednak strony, postanowienia kontraktowe kształtowane z wyłącznej inicjatywy zamawiającego, dotyczące przede wszystkim ilości i jakości oraz terminu spełnienia zamawianego świadczenia niepieniężnego, powinny być w pełni dostosowane do celu umowy związanego z zaspokojeniem potrzeb publicznych.

W związku z potrzebą polepszenia ochrony interesów wykonawców nasunęła się konieczność zwalczania w trybie odwoławczym klauzul abuzywnych praktykowanych na niekorzyść wykonawcy w oderwaniu od istoty zawieranej umowy. Dotychczasowa chwiejność orzecznictwa wynikająca z niezbyt jasnych kryteriów zaskarżania projektowanych postanowień umowy spotkała się z interwencją legislacyjną. W świetle art. 433 nowego p.z.p. projektowane postanowienia umowy nie mogą przewidywać odpowiedzialności wykonawcy za spóźnienie usprawiedliwione lub naliczania kar umownych z tytułu okoliczności przez wykonawcę niezawinionych czy odpowiedzialności za zdarzenia obciążające wyłącznie samego zamawiającego, a także możności ograniczenia zakresu zamówienia bez wskazania minimalnej jego wielkości lub wartości. Ten zamknięty katalog budzi jednak zastrzeżenia, przede wszystkim dlatego, że nie jest pełny (spotęguje niewątpliwie trudności w orzecznictwie), a skoro taki być nie powinien - należało raczej wprowadzić generalny zakaz stosowania klauzul krzywdzących wykonawców z przykładowym wskazaniem kilku przypadków szczególnych. Sytuację ratuje nieco art. 554 nowego p.z.p., legitymujący KIO do orzekania w szerszym zakresie, a mianowicie o „niezgodności projektowanych postanowień umowy z wymaganiami wynikającymi z ustawy". W ramach kryterium definicyjnego trzeba odwoływać się do legalności, a zatem do naruszenia prawa, dobrych obyczajów (ich przestrzeganie jest oczekiwane), a także zasad udzielania zamówień publicznych, które mają zresztą także charakter normatywny. Kryterium legalności stanowi bowiem podstawę orzekania przez Krajowa Izbę Odwoławczą, która niekiedy zapomina — niestety — o pozaustawowych jej wyznacznikach, a zwłaszcza o zasadzie proporcjonalności. Sam ustawodawca też nie jest w pełni konsekwentny, operując $\mathrm{w}$ art. 179 ust. 1 p.z.p. „naruszeniem przez zamawiającego przepisów niniejszej ustawy" tytułem podstawowej przesłanki stosowania środków ochrony prawnej. Wprawdzie w art. 505 nowego p.z.p. złagodzono nieco ten rygoryzm, pomijając słowo „niniejszej”, tak że liczy się już każde naruszenie prawa przedmiotowego, jednak w wypadku naruszenia dobrych obyczajów lub zasad udzielania zamówień nadal nawiązywać trzeba pośrednio, uwzględniając przepisy do nich odsyłające.

Spośród ograniczeń swobody kształtowania treści umowy wynikających wprost z przepisów ustawy odnotować należy w szczególności: a) wykaz obligatoryjnych postanowień umowy; b) zakaz naruszania zakresu świadczenia wykonawcy ustalonego uprzednio w warunkach zamówienia; c) warunki dopuszczenia tak zwanego prawa opcji; d) zakaz udzielania zamówień bezterminowych; 
e) wymóg wprowadzenia klauzuli indeksacyjnej do umowy długoterminowej; f) zakaz wyłączenia podwykonawstwa w odniesieniu do ubocznych części zamówienia; g) podstawy odpowiedzialności zamawiającego za zapłatę wynagrodzenia należnego podwykonawcy budowlanemu; h) wykluczenie przedpłat oraz limitowanie zaliczek na rzecz wykonawcy; i) klauzule związane z ochroną danych osobowych; j) maksymalny termin zapłaty; k) elektroniczne fakturowanie należności oraz 1) limitowanie form zabezpieczenia należytego wykonania umowy ${ }^{23}$. Nie można zaś rozpatrywać w kategoriach ograniczenia swobody kontraktowej postprzetargowego obowiązku zawarcia umowy finalnej (art. 94 p.z.p.), skoro pod względem konstrukcyjnym łączy się bezpośrednio z umową przedwstępną w ujęciu art. 389 k.c., a zatem stanowi wynik dobrowolnego samoograniczenia się kontrahentów. Pomijać należy tu także wszelkie przepisy instrukcyjne, zwłaszcza przewidujące, że stronom coś wolno, podczas gdy to samo im wolno w oparciu o ogólną zasadę swobody kontraktowej.

Nowością jest wykaz obligatoryjnych postanowień umowy, który od niedawna dotyczył tylko umów budowlanych (art. 143d p.z.p.), natomiast w przyszłości ten sposób reglamentacji ustawowej dotknie wszystkie rodzaje umów (por. art. 436 nowego p.z.p.). W praktyce jest wysoce dyskusyjny, choć ma na celu zapobieganie rozmaitym nieprawidłowościom krzywdzącym wykonawców lub popełnianym na szkodę interesu publicznego. Chodzi o dodatkowe zastrzeżenia umowne w odniesieniu do sposobu ustalenia terminu realizacji zamówienia (pojmowanego z zasady w kategoriach okresu, a nie sztywnej daty), warunków zapłaty wynagrodzenia należnego wykonawcy, maksymalnej wysokości kar umownych oraz sposobu indeksacji wynagrodzenia wynikającego z umowy długoterminowej. W umowach budowlanych konieczne są jeszcze dodatkowe zastrzeżenia, a mianowicie - w sprawie procedury wyrażenia zgody na dopuszczenie konkretnego podwykonawcy do realizacji zamówienia, zasad zawierania umów przez wykonawcę z podwykonawcami, uwarunkowania zapłaty bezpośredniej przez zamawiającego wynagrodzenia należnego podwykonawcy oraz kar umownych za łamanie związanych z tymi klauzulami powinności. Ponadto doniosłe znaczenie praktyczne w odniesieniu do zamówień usługowych i budowlanych mają przepisy wskazujące na zastrzeżenie w umowie sposobu kontroli przez zamawiającego zatrudnienia po stronie wykonawcy osób na podstawie umowy o pracę czy też warunków zatrudnienia tak zwanych osób defaworyzowanych. Niejasny jest jednak charakter tych regulacji, zwłaszcza z punktu widzenia sankcji na wypadek pominięcia w umowie wskazanych klauzul albo wadliwego ich wprowadzenia. Jak się zdaje, są to tylko zalecenia ustawowe, $\mathrm{z}$ braku dostatecznych podstaw do zastosowania sankcji nieważności umowy, choć obowiązek ich wprowadzenia może być dochodzony w trybie odwoławczym. Wprawdzie z art. 436-439 nowego p.z.p. wynika

23 Więcej o tym zob. R. Szostak, Umowy o zamówienia publiczne w zarysie, Warszawa 2018, s. $41 \mathrm{n}$. 
wyraźnie, że są one adresowane do obu stron umowy o zamówienie publiczne, lecz ochrona interesów wykonawcy pozbawionego realnego wpływu na ukształtowanie ostatecznych postanowień umowy sprzeciwia się zastosowaniu sankcji nieważności całej umowy na podstawie art. $58 \S 1$ k.c. Natomiast dla rygoru nieważności częściowej, ograniczającej się jedynie do wadliwych lub brakujących postanowień umowy, brakuje zwyczajnej sposobności, aby zbyt ogólna dyspozycja naruszonego przepisu mogła wejść automatycznie do treści umowy, tak jak na przykład w wypadku nieokreślenia terminu zapłaty wchodzi trzydziestodniowy termin ustawowy. Poza tym sam ustawodawca wskazuje niekiedy odmienne następstwo, na przykład co do klauzul indeksacyjnych uprawniających jedynie do żądania zmiany umówionego wynagrodzenia. W rezultacie w ramach sankcji pozostaje w zasadzie tylko odpowiedzialność służbowa czy nawet dalej idąca odpowiedzialność administracyjna osób zarządzających zamówieniami po stronie instytucji zamawiających.

Zupełnie inaczej kwalifikować trzeba zakaz przekroczenia w zawieranej umowie finalnej przedmiotowego zakresu zamówienia określnego uprzednio w jego warunkach (ogłoszeniu), który został unormowany w art. 140 p.z.p., pod rygorem unieważnienia części umowy wykraczającej poza ten zakres. Pominięcie odpowiednika tego przepisu w nowej ustawie budzi wątpliwości. Wprawdzie to samo można wywieść $\mathrm{z}$ mechanizmu obowiązku zawarcia umowy w ujęciu art. 389-390 k.c., jednak skoro i on sam nie przedstawia się dostatecznie przejrzyście, w praktyce łatwiej będzie o niedozwolone obejście wyniku przetargu poprzez zawarcie umowy odbiegającej od ogłoszonego uprzednio przedmiotu zamówienia. Zaprzeczeniem tej tendencji jest art. 441 nowego p.z.p., wskazujący na warunki skorzystania przez zamawiającego z tak zwanego prawa opcji, choć rysująca się luka legislacyjna (wynikająca z brakującego odpowiednika art. 140 p.z.p.) może zostać usunięta poprzez to unormowanie tylko częściowo, zwłaszcza w trybie wnioskowania a fortiori. Dyspozycje umowne w sprawie opcji, zwłaszcza polegające na uwarunkowaniu wymagalności części zamówionego świadczenia, słusznie powinny określać jej rodzaj i maksymalną wartość oraz okoliczności uprawniające zamawiającego do skorzystania z zastrzeżonego prawa, z wykluczeniem jednak możliwości modyfikacji ogólnego charakteru kontraktu, pod rygorem unieważnienia czynności (dyspozycji) wykonawczych. Zasada, że umowy o zamówienia publiczne kreują zobowiązania terminowe jest bezdyskusyjna na tle wymogu nieprzerwanego zaspokajania potrzeb publicznych, a wymuszone potrzebą wyeliminowania szkodliwych nawyków nowe przepisy o charakterze lex specialis w sprawie prawidłowego konstruowania terminu wykonania zamówienia, jego znaczenia prawnego i sposobu liczenia, wobec jednoznacznych i zgodnych z odwieczną tradycją dyspozycji kodeksowych, zostaną niewątpliwie w przyszłości skreślone. To samo dotyczy przepisów o obligatoryjnych karach umownych, które jedynie limitują wolę stron, nie ustalając — szczęśliwie — żadnych stawek tych kar. Pomimo postulatów doktrynalnych brakuje w nowej ustawie podstaw do uznania umowy bezterminowej za nieważną, pozostają zatem ogólne konsekwencje zobowiązań bezterminowych z uwzględnieniem art. 455 k.c. 


\section{Ograniczenie możliwości zmiany lub rozwiązania umowy o zamówienie publiczne}

Charakter zamówienia publicznego, zorientowanego na zaspokajanie potrzeb zbiorowych, koliduje ze swobodą w zakresie zmiany umowy bądź przedwczesnego jej rozwiązania. Dlatego unormowania wzmacniające ogólną zasadę pacta sunt servanda i towarzyszący jej wymóg realnego wykonania zobowiązania (art. 354 k.c.) są obecne w regulacji umów o zamówienia publiczne, z tradycyjnym zakazem zmiany umowy na niekorzyść zamawiającego. Niedawno doszły jeszcze rozwiązania europejskie na rzecz ochrony zasad równości, uczciwej konkurencji i przejrzystości przy udzielaniu zamówień publicznych, sprzeciwiające się wprowadzaniu zmian do umowy finalnej, zmierzających do obejścia wyniku przetargu bądź innej procedury ofertowo-porównawczego udzielenia zamówienia. Odzwierciedleniem obu tych tendencji są unormowania zawarte w art. 144 oraz $\mathrm{z}$ art. 145a p.z.p., zmodernizowane ostatnio na mocy art. 454-460 nowego p.z.p. Zakazuje się przede wszystkim zmian istotnych umowy, prowadzących do modyfikacji jej charakteru prawnego, a w szczególności: a) naruszających równowagę ekonomiczną na korzyść wykonawcy; b) znacznie rozszerzających albo zmniejszających zakres świadczeń lub zobowiązań stron; c) wprowadzających nowe warunki kontraktowe, takie, że gdyby z góry zostały dopuszczone, mogłyby zainteresować innych wykonawców ubieganiem się o zamówienie, a także d) zmian zmierzających do zastąpienia wykonawcy inna osobą ${ }^{24}$. Nie dotyczy to jednak zmian $\mathrm{z}$ góry zapowiedzianych $\mathrm{w}$ warunkach zamówienia na podstawie stosownej klauzuli adaptacyjnej, nawet dopuszczającej zastąpienie wykonawcy inną osobą, a także zmian polegających na zakontraktowaniu dodatkowych dostaw, usług lub robót budowlanych o wartości nieprzekraczającej 50\% pierwotnego zamówienia, jeżeli stały się one niezbędne, a wyłączeniu dotychczasowego wykonawcy sprzeciwiają się względy ekonomiczne lub techniczne powodujące istotną niedogodność lub znaczne zwiększenie kosztów po stronie zamawiającego (art. 455 nowego p.z.p.) ${ }^{25}$. Specjalne znaczenie ma ponadto możność zmiany umowy spowodowana okolicznościami, których zamawiający działający z należytą starannością nie mógł przewidzieć, o ile nie pociąga ona modyfikacji charakteru ogólnego stosunku, a ewentualny wzrost ceny nie przekroczy $50 \%$ pierwotnej wartości umowy (art. 455 ust. 1 pkt 4 nowego p.z.p.). Przypadek ten nie wyłącza bynajmniej zastosowania tradycyjnej klauzuli rebus sic stantibus $\mathrm{z}$ art. $357^{1}$ k.c., uprawniającej do jednostronnego żądania sądowej zmiany lub rozwiązania umowy z powodu nadzwyczajnej zmiany stosunków zaistniałej po

24 Więcej zob. R. Szostak, Umowy o zamówienia publiczne..., s. 195 n.

${ }^{25} \mathrm{~W}$ pełni swobodne są natomiast zmiany umów małej wartości polegające na rozszerzeniu zakontraktowanych dostaw lub usług o wartości do $10 \%$, a robót do $15 \%$, w stosunku do pierwotnej wartości świadczenia. 
udzieleniu zamówienia, której wcześniej strony nie mogły przewidzieć ${ }^{26}$. Jednocześnie jednak ograniczenia swobody kontraktowej w zakresie dopuszczalnych zmian umowy są aktualne także w wypadku zawarcia ugody w ujęciu art. 917 k.c., zwłaszcza jeśli podlegałaby ona modyfikacji zobowiązania obciążającego wykonawcę.

Podobnie zakazuje się przedwczesnego rozwiązywania umów, zarówno $\mathrm{w}$ trybie jednostronnego odstąpienia lub wypowiedzenia, jak i w drodze dobrowolnego porozumienia stron (argumentum a fortiori). Nieliczne wyjątki określa ustawa, choć liczą się tu nie tylko przypadki wskazane bezpośrednio w art. 145a p.z.p. (art. 456 nowego p.z.p.), lecz także wynikające z kodeksu cywilnego lub przepisów odrębnych. W istocie zatem zakazuje się zastrzegania umownego prawa odstąpienia od umowy lub jej wypowiedzenia (możliwe jest tylko skorzystanie z prawa ustawowego), a także zgodnego samorozwiązania umowy przez strony, choć dopuszczalne jest porozumienie stron rozwiązujące przedwcześnie zobowiązanie z powodu takich samych przyczyn publicznych, jakie uzasadniają jej rozwiązanie jednostronne przez zamawiającego ${ }^{27}$. Niezależnie od przypadków przewidzianych w kodeksie lub w przepisach odrębnych zamawiający może odstąpić od umowy w trzech sytuacjach szczególnych, a mianowicie w razie: a) zaistnienia istotnej zmiany okoliczności powodujących, że wykonanie umowy nie leży w interesie publicznym, czego nie dało się z góry przewidzieć lub dalsze wykonywanie umowy może zagrażać interesowi bezpieczeństwa państwa lub bezpieczeństwu powszechnemu; b) dokonania uprzednio zakazanej zmiany umowy uzasadniającej następnie jej zniesienie w trybie wypowiedzenia (częściowego); c) gdy wykonawca w chwili zawarcia umowy podlegał wykluczeniu, zwłaszcza w wypadku wyłudzenia zamówienia. Z kolei wykonawca może jednostronnie odstąpić od umowy tylko na zasadach ogólnych, na przykład w razie braku współdziałania ze strony zamawiającego (art. 640 k.c.), zaniechania przez zamawiającego ustanowienia gwarancji zapłaty za wykonane roboty budowlane (art. $649^{4}$ k.c.) lub zaistnienia ważnego powodu utrudniającego wykonanie zlecenia (art. $746 \S 2$ k.c.).

\section{Bibliografia}

Brzozowski A., Wpływ zmiany okoliczności na zobowiązanie. Klauzula rebus sic stantibus, Warszawa 2014.

Buczkowski S., Zasada wolności umów, „Państwo i Prawo” 1961, nr 3.

26 Por. W. Robaczyński, Sądowa zmiana umowy, Warszawa 1998, s. 13 n.; oraz A. Brzozowski, Wpływ zmiany okoliczności na zobowiązanie. Klauzula rebus sic stantibus, Warszawa 2014, s. $41 \mathrm{n}$.

27 Por. R. Szostak, Umowy o zamówienia publiczne..., s. 220-223. 
Czachórski W., Prawo zobowiąań w zarysie, Warszawa 1970.

Drozdowicz M., Zawarcie umowy o zamówienie publiczne w formie elektronicznej, „Prawo Zamówień Publicznych" 2019, nr 2.

Grzybowski S., Prawo cywilne - zarys części ogólnej, Warszawa 1974.

Horubski K., Prawne uwarunkowania wplywu wykonawców na treść umów o zamówienia publiczne, „Prawo” 329, 2019.

Jakubowski J., Umowa sprzedaży w handlu międzynarodowym, Warszawa 1966.

Koschembahr-Łysakowski J., W sprawie kodyfikacji naszego prawa cywilnego, Warszawa 1925.

Krajewski M., Zobowiąania powstajace podczas zawierania umów, [w:] System Prawa Prywatnego, t. 5. Prawo zobowiazań - częśś ogólna, red. E. Łętowska, Warszawa 2006.

Machnikowski P., Swoboda umów, [w:] System Prawa Prywatnego, t. 5. Prawo zobowiazań część ogólna, red. E. Łętowska, Warszawa 2006.

Machnikowski P., Swoboda umów wedlug art. $353^{1}$ k.c. Konstrukcja prawna, Warszawa 2005.

Moras M., [w:] Informatyzacja procedur udzielania zamówień publicznych, red. R. Szostak, Warszawa 2018.

Ohanowicz A., Wolność umów w przyszłym polskim kodeksie cywilnym, „Ruch Prawniczy, Ekonomiczny i Socjologiczny" 1926, nr 3.

Radwański Z., System Prawa Prywatnego, t. 2. Prawo cywilne - część ogólna (suplement), Warszawa 2004.

Radwański Z., Teoria umów, Warszawa 1977.

Rajski J., Aukcja i przetarg w ujęciu znowelizowanych przepisów kodeksu cywilnego, „Przegląd Prawa Handlowego" 2003, nr 4.

Rajski J., Prawo o kontraktach w obrocie gospodarczym, Warszawa 2002.

Robaczyński W., Sadowa zmiana umowy, Warszawa 1998.

Sołtysińska A., Europejskie prawo zamówień publicznych. Komentarz, Warszawa 2016.

Szostak R., Jawność i przejrzystość postępowania o udzielenie zamówienia publicznego, „Samorząd Terytorialny" 2019, nr 5.

Szostak R., Odpowiedzialność organizatora przetargu za szkody wyrzadzone konkurentom, „Państwo i Prawo" 2011, nr 10.

Szostak R., Przetarg nieograniczony na zamówienie publiczne — zagadnienia konstrukcyjne, Kraków 2004.

Szostak R., Umowy o zamówienia publiczne w zarysie, Warszawa 2018.

Szostak R., Zamówienia publiczne instrumentem stymulacji rozwoju gospodarczego [w:] Prawne instrumenty oddziatywania na gospodarke, red. A. Powałowski, Warszawa 2016.

Trzaskowski R., Granice swobody ksztaltowania treści i celu umów obligacyjnych (art. $353^{1}$ k.c.), Kraków 2005.

Wolter A., Czy art. 55 kz obowiazuje?, „Nowe Prawo” 1960, nr 10.

Żuławska C., Komentarz do kodeksu cywilnego. Księga trzecia - zobowiazania, t. 1, Warszawa 2005.

Żuławska C., Wokót zasady wolności umów (art. $353^{1}$ k.c. i wyktadnia zwyczaju), „Prawo ” 238, 1994.

Żuławska C., Zasady prawa gospodarczego, Warszawa 1995. 


\title{
Selected issues in rationalization of restrictions on contractual freedom in public procurement
}

\begin{abstract}
Summary
Contractual freedom is present in public procurement despite various restrictions. The greatest restrictions come from the area of legislation, and are characteristic for parametric economic control, while individual administrative intervention is of secondary importance. As regards the choice of the type of contract, the restrictions are sporadic, because the Act does not state when and what kind of contracts may be awarded by public sector entities. Entrepreneurs also apply for individual contracts on a voluntary basis. However, a ban on direct transactions justifies highly inconvenient bureaucratic rationing of public procurement procedures, although the will of the parties is of fundamental importance here, especially when constructing procedural conditions, and the Act plays only a supplementary role here. Restrictions regarding the formulation of the content of the contract are equally burdensome. The use of mandatory clauses, imposed by law, is increasing, and normative principles of public procurement are becoming more and more rigorous, which is justified by the need for increased protection of the public interest. Freedom in the remaining areas is often abused by the contracting authority, who sets the provisions of the agreement in advance. Therefore, the recently regulated possibility of fighting abusive clauses in an appeal procedure is of great practical significance. At the same time, while strengthening the principle of real contract implementation, which excludes the possibility of circumventing the results of the tender, a ban has been introduced on making major changes to public procurement contracts and on premature termination of such contracts. The progressive computerization of public procurement is expected to alleviate formal and bureaucratic obstacles.
\end{abstract}

Keywords: contract, freedom of contract, public procurement, tender. 